\title{
Migration/Refugee Law (2018)
}

\author{
Matthew Scott*
}

2018 may come to be seen as the year in which cross-border human mobility in the context of disasters and climate change moved from being a relatively niche concern of academics, some UN agencies and a number of concerned States towards becoming an issue of concerted international attention. This shift is evident in developments at international as well as regional levels, as summarised below. In addition, marking the 2oth anniversary of the 1998 Guiding Principles on Internal Displacement, 2018 also saw increased legal and policy focus on the majority who are displaced within their own countries.

\section{International Developments}

\subsection{The Global Compact for Safe, Orderly and Regular Migration and the Global Compact on Refugees}

Without doubt, the Global Compact for Safe, Orderly and Regulation Migration $(\mathrm{GCM})^{1}$ and the Global Compact on Refugees (GCR $)^{2}$ that were endorsed by the UN General Assembly in December 2018 represent the most significant international development relating to human mobility in the context of disasters and climate change in 2018. The result of two years of consultations and negotiations following on from the 2016 New York Declaration for Refugees and Migrants, ${ }^{3}$ the Global Compacts, despite being non-binding, have variously been heralded as reflecting 'broad and overwhelming support', ${ }^{4}$ cautiously acknowledged as signalling 'new moral and political undertakings by

* Senior Researcher, Head of People on the Move thematic area, Raoul Wallenberg Institute of Human Rights and Humanitarian Law. The author thanks Alice Sironi and others at Iом and Juan Carlos Méndez Barquero of the Platform on Disaster Displacement for contributing information for this article.

1 UNGA Res 73/195 (11 January 2019) UN Doc A/RES/73/195.

2 UNGA Res 73/151 (10 January 2019) UN Doc A/RES/73/151.

3 UNGA Res 71/1 (19 September 2016) UN Doc A/RES $/ 71 / 1$.

4 Volker Türk, 'The Promise and Potential of the Global Compact on Refugees' (2018) 30 International Journal of Refugee Law 575, 582 . 
the world's governments' 5 and derided as a 'global cop-out'. ${ }^{6}$ The Compacts are particularly noteworthy in the present context as they signal widespread recognition of the phenomenon of cross-border displacement and migration in the context of disasters and climate change, a reality States were not prepared to acknowledge just seven years earlier. ${ }^{7}$

The Global Compact on Refugees is significant for its recognition of disasters and climate change as drivers of cross-border human mobility, which often interact with conventional drivers of refugee movements. ${ }^{8}$ The GCR promotes disaster risk reduction (DRR) measures as a way of addressing root causes of cross-border displacement and calls for the inclusion of refugees in DRR initiatives. ${ }^{9}$ However, the Compact avoids addressing the role of the ${ }^{1951}$ Convention Relating to the Status of Refugees and its 1967 Protocol in this context. ${ }^{10}$ Using notably vague language, paragraph 63 highlights:

Measures to assist those forcibly displaced by natural disasters, taking into account national laws and regional instruments as applicable, as well as practices such as temporary protection and humanitarian stay arrangements, where appropriate.

Whilst not recognising the potential application of the 1951 Convention, the GCR seems to acknowledge the potential application of regional refugee instruments such as the 1984 Cartagena Declaration on Refugees and the 1969 Organization of African Unity Convention Governing the Specific Aspects of Refugee Problems in Africa as having relevance in this context. ${ }^{11}$

Jane McAdam, 'Editorial: The Global Compacts on Refugees and Migration: A New Era for International Protection?', (2018) 30 International Journal of Refugee Law, 571.

6 James Hathaway, 'The Global Cop-Out on Refugees', (2018) 30 International Journal of Refugee Law, 591 .

7 See Walter Kälin, 'From the Nansen Principles to the Nansen Initiative', (2012) 41 Forced Migration Review, 48.

8 See paras. 8 and 12.

9 See paras. 9, 53 and 79 .

10 For comprehensive treatment of this question in relation to the 1951 Refugee Convention, see Matthew Scott, Climate Change, Disasters and the Refugee Convention (cuP, forthcoming).

11 For treatment of regional refugee instruments, see Sanjula Weerasinghe, 'In Harm's Way: International Protection in the Context of Nexus Dynamics between Conflict or Violence and Disaster or Climate Change' UnHCR Legal and Protection Policy Research Series PPLA/2018/05 (December 2018), available at <https://www.unhcr.org/5c1ba88d4.pdf>, last accessed (as any subsequent URL) on 10 April 2019. 
Seen as much more of a breakthrough, ${ }^{12}$ the Global Compact for Migration reflects many of the key insights of the 2015 Agenda for the Protection of CrossBorder Displaced Persons in the Context of Disasters and Climate Change. ${ }^{13}$ For example, the GCM emphasises the importance of disaster risk reduction and climate change adaptation as measures to reduce displacement risk, and dedicates a specific subsection within Objective 2 on minimizing the adverse drivers and structural factors that compel people to leave their country of origin to 'natural disasters, the adverse effects of climate change, and environmental degradation'. Further, Objective 5 calls upon States to develop and build on existing effective practices relating to the admission and stay of persons displaced across borders in the context of disasters and climate change, with both sudden and slower-onset processes in focus. ${ }^{14}$

Both Global Compacts are non-binding documents, and therefore in themselves do not create any new obligations relating to human mobility in the context of disasters and climate change. However, with 181 votes in favour of the $\mathrm{GCR}$ and $15^{2}$ votes in favour of the $\mathrm{GCM},{ }^{15}$ the documents provide a strong platform for further policy and legal engagement with the issue.

\subsection{The Plan of Action for Advancing Prevention, Protection and Solutions for Internally Displaced People 2018-2020}

In addition to the developments on cross-border displacement discussed above, a significant development in the area of internal human mobility entailed the launch of The Plan of Action for Advancing Prevention, Protection and Solutions for Internally Displaced People 2018-2020 by the UN Special Rapporteur on the Rights of Internationally Displaced Persons, marking the 2oth anniversary of the 1998 Guiding Principles on Internal Displacement. ${ }^{16}$ Responding to the call by the UN General Assembly for 'States, UN entities, the Special Rapporteur on the Human Rights of IDPs, regional organizations, national human rights institutions, NGOs and other stakeholders to mark the

12 See for example Walter Kälin, 'The Global Compact on Migration: A Ray of Hope for Disaster-Displaced Persons' (2018) 30 International Journal of Refugee Law 664.

13 The Nansen Initiative, 'Global Consultation Report' (12-13 October 2015), available at $<$ https://www.nanseninitiative.org/global-consultations/>.

14 Objective $5(\mathrm{j})$ addresses more sudden onset hazard events and Objective $5(\mathrm{~h})$ addresses slower-onset processes.

15 Details of the endorsement of the GCM are available at <https://www.un.org/press/ en/2018/ga12113.doc.htm > and details of the endorsement of the GCR are available at $<$ https://www.un.org/press/en/2018/ga12107.doc.htm>.

16 UN News, 'UN launches global plan to strengthen protection of internally displaced persons' (18 April 2018) <https://news.un.org/en/story/2018/04/1007552>. 
2oth anniversary in 2018 of the Guiding Principles on Internal Displacement,', ${ }^{17}$ the Plan of Action calls attention to the fact that millions of people are internally displaced in the context of disasters every year, and that millions more are expected to be displaced in coming years as the impacts of climate change are increasingly felt. ${ }^{18}$ The Plan of Action is an initiative to raise awareness and promote relevant action, and therefore, like the Guiding Principles themselves, has no binding legal force.

The Plan aims to 'reduce and resolve internal displacement through prevention, protection and solutions for ID Ps' and highlights key activities to contribute towards that goal, including increasing participation of IDPs, enhancing collection, analysis and use of data on internal displacement, expanding the development and implementation of national law and policy on internal displacement and promoting action in alignment with the Sustainable Development Goals. The Plan is expressly aligned with the Sendai Framework for Disaster Risk Reduction, the Paris Climate Agreement and other international policy agendas.

\subsection{UNFCc WIM Taskforce on Displacement Recommendations}

In December, the Executive Committee of the Warsaw International Mechanism for Loss and Damage considered a detailed report from the UNFCCC Taskforce on Displacement that summarizes conclusions derived from a series of mapping and consolidation activities, focusing on legal, policy and operational frameworks relating to displacement in the context of disasters and climate change. ${ }^{19}$ Drawing on the recommendations in this report, the Executive Committee delivered almost 20 recommendations to the 24th Conference of the Parties in Katowice. ${ }^{20}$ A selection of the more legally relevant recommendations include:

- Promoting the formulation of laws, policies and strategies, as appropriate, that reflect the importance of integrated approaches to avert, minimize and

17 UNGA, 'Protection of and Assistance to Internally Displaced Persons' UN Doc A/C.3/72/L.46/Rev.1 (14 November 2017).

18 Plan of Action for Advancing Prevention, 'Protection and Solutions for Internally Displaced People 2018-2020', available at <http://www.globalprotectioncluster.org/_assets/ files/20180523-gp2o-plan-of-action-final.pdf>.

19 UNFCCC Task Force on Displacement, 'Report of the Task Force on Displacement' (17 September 2018), available at <https://unfccc.int/sites/default/files/resource/2018_TFD_ret port_17_Sep.pdf>.

20 See Decision -/CP.24 (Advance unedited version), 'Report of the Executive Committee of the Warsaw International Mechanism for Loss and Damage associated with Climate Change Impacts', available at <https://unfccc.int/sites/default/files/resource/cp24_auv_ ec\%2owim.pdf>. 
address displacement related to the adverse impacts of climate change and in the broader context of human mobility, taking into consideration their respective human rights obligations and, as appropriate, other relevant international standards and legal considerations

- To recall the guiding principles on internal displacement and seek to strengthen efforts to find durable solutions for internally displaced people

- Invite relevant United Nations agencies and other stakeholders to engage with bodies under the Convention, especially the Executive Committee, when facilitating the efforts of States to address challenges and opportunities associated with climate change related human mobility, including the Global Compact for Migration and the work of the international migration review forum, the United Nations Network on Migration and other relevant international frameworks and programmes of action, as appropriate, to avoid duplication on climate change aspects.

The mandate of the Task Force was extended by the Conference of the Parties for a further five-year period, ${ }^{21}$ and the Executive Committee will continue to promote research and action to address the issue, including by facilitating the mobilization of financial resources for developing country Parties to avert, minimize and address displacement related to the adverse effects of climate change. $^{22}$

\subsection{UNDRR Words into Action Guidelines}

The Words into Action Guidelines, ${ }^{23}$ launched for global consultation in 2018, represent the effort of the UN Office for Disaster Risk Reduction (UNDRR) to articulate the range of measures that States and other actors can take to address displacement risk within the context of the Sendai Framework on Disaster Risk Reduction (SFDRR). ${ }^{24}$ The Guidelines, developed with the support of key international actors engaged in disaster displacement and in consultation with governments, are designed to assist States in addressing target $\mathrm{E}$ of the Sendai Framework: 'to revise or develop DRR strategies by 2020'. The

\footnotetext{
21 Ibid., para. $5(\mathrm{~b})$.

22 UNFCCC, 'Report of the Executive Committee of the Warsaw International Mechanism for Loss and Damage Associated with Climate Change Impacts FCCC/SB/2018/1' (15 October 2018), available at $<$ https://undocs.org/FCCC/SB/2018/1>.

23 UNDRR, 'Words into Action Guidelines - Disaster Displacement: How to Reduce risk, address impacts and strengthen resilience (Public consultation version)' (2018), available at $<$ https://www.unisdr.org/we/inform/publications/58821>.

24 The Words into Action Guidelines are a series of about 30 thematic papers, each dealing with a different aspect of DRR implementation. See <https://www.preventionweb.net/ sendai-framework/wordsintoaction>.
} 
Guidelines identify relevant measures relating to the prevention of displacement, protection during displacement and facilitation of durable solutions to displacement in the context of disasters and climate change. The Guidelines add to an already extensive array of non-binding guidelines and standards relating to different aspects of displacement, ${ }^{25}$ raising the possibility that they will increase the volume of principles, methodologies and recommendations that national and sub-national actors ought to consider when addressing displacement risks and realities. However, as the Guidelines are directly integrated into the SFDRR process, and indeed directly linked to a specific target within this Framework, they provide an important tool to promote the further integration of displacement into national and sub-national disaster risk reduction and climate change adaptation law and policy.

\subsection{The Sydney Declaration of Principles on the Protection of Persons Displaced in the Context of Sea Level Rise}

The International Law Association adopted at its 78 th session the Sydney Declaration of Principles on the Protection of Persons Displaced in the Context of Sea Level Rise. ${ }^{26}$ Detailed commentary to each of the nine principles can be found at Part III of the 2018 Sydney conference report. ${ }^{27}$ The Declaration and the associated commentary has significance as a consolidation of international law applying to the specific situation of displacement in the context of sealevel rise. It builds expressly on the International Law Commission's Draft Articles on the Protection of Persons in the Event of Disasters by highlighting, inter alia, the duty to respect the human rights of affected persons. ${ }^{28}$ The remainder of the Declaration elaborates how international human rights law in particular, but also the UN Framework Convention on Climate Change principle of common but differentiated responsibility, establishes duties on both the affected State as well as the international community to take steps to

25 For a summary of relevant international standards and guidelines, see Matthew Scott, 'Background Brief on Key International Standards and Guidelines Relating to Displacement in the Context of Disasters and Climate Change' (Raoul Wallenberg Institute 2018), available at <https://rwi.lu.se/publications/background-brief-key-inter national-standards-and-guidelines-relating-to-displacement-in-the-context-of-disastersand-climate-change/>.

26 ILA Committee on International Law and Sea Level Rise, Resolution 6/2018, available at <http://www.ila-hq.org/images/ILA/Resolutions/ILAResolution_6_2018_SeaLevelRise_ SydneyDeclaration.pdf $>$.

27 See <http://www.ila-hq.org/index.php/committees $>$.

28 Reflected in draft article 2 of ILC Draft Articles on the Protection of Persons in the Event of Disasters. 
address risks associated with sea level rise (Principles 3-4). Facilitation of cross-border mobility is identified as one relevant form of international cooperation. Other elements included in the Declaration include evacuation, planned relocation, internal displacement and cross-border displacement. As a consolidated reflection of international law relating to human mobility in the context of sea level rise, the Declaration and Commentary provide an accessible reference document for considering measures to address this phenomenon.

\section{3}

\section{Regional Developments}

\subsection{Asia}

The seventh biennial Asian Ministerial Conference on Disaster Risk Reduction, taking place in July 2018 and bringing together senior officials working on disaster risk reduction from across Asia and the Pacific, led to the adoption of a non-binding Ulaanbaatar Declaration which includes a number of significant statements on disaster displacement that anchor disaster risk reduction initiatives in the region within a framework that not only recognises the reality of disaster displacement, but also endorses a human rights-based approach to addressing the phenomenon. ${ }^{29}$ The Declaration for example calls upon governments and stakeholders to " $[\mathrm{e}]$ nsure a human rights-based, people-centred and whole-of-society approach in development, implementation and monitoring of national and local disaster risk reduction strategies' and expresses 'deep concern at the continuing impact of disasters in the region, resulting in recurrent loss of human lives and livelihoods, displacement of people, and environmental, economic, social and material damages'. The regional momentum will continue to gather as the decision was taken in 2018 to make disaster displacement one of the four themes for the 2020 Conference to be hosted by Australia. ${ }^{30}$

\subsection{The Americas}

In November, the South American Conference on Migration (SACM) adopted the 'Lineamientos Regionales en Materia de Protección y Asistencia a Personas

29 Asian Ministerial Conference on Disaster Risk Reduction, Ulaanbaatar Declaration (6 July 2018), available at <https://www.preventionweb.net/files/56219_ulaanbaatardeclarationfinal.pdf $>$.

3o Author communication with UNDRR Regional Office for Asia and the Pacific (ROAP), 1 March 2019. 
Desplazadas a Través de Fronteras y Migrantes en Países Afectados por Desastres de Origen Natural', a guide to effective practices on cross-border disasterrelated displacement. ${ }^{31}$ The document addresses contingency measures to reduce and avoid the risk of displacement in the country of origin (Part IV), protection of cross-border disaster displaced persons, including humanitarian assistance, admission and stay, protection during displacement and durable solutions (Part v) and protection of migrants in countries affected by disasters (Part VI). Part III of the agreement sets out a number of principles, including cooperation and solidarity, sovereignty and exercise of discretion in migration matters, respect for human rights and non-discrimination, needs and vulnerability-based attention focusing on specific populations, including the sick and wounded, children, female headed households, persons with disabilities, victims of trafficking, members of minority ethnic and indigenous groups who may reside in the transboundary zone, amongst others.

Meanwhile, reflecting wider trends in countries of the global North to seek to curtail legal avenues to protection for cross-border displaced persons, the United States decided ${ }^{32}$ to terminate the Temporary Protected Status designations of people from El Salvador, Haiti, Nicaragua, and Sudan, although legal action in the case of Ramos $v$. Nielsen was preventing enforcement of the decision by the end of the year. ${ }^{33}$ Temporary Protected Status can be granted to citizens of countries affected by disasters in accordance with 8 U.S.C., Section 1254a. As disasters and other environmental factors lay behind the decision to grant TPS to nationals of each of these countries, ${ }^{34}$ the decision to terminate such status is highly relevant to the annual review. The decision of 3 October 2018 has been appealed to the U.S. Court of Appeals for the Ninth Circuit. ${ }^{35}$

31 South American Conference on Migration, 'Lineamientos Regionales en Materia de Protección y Asistencia a Personas Desplazadas a Través de Fronteras y Migrantes en Países Afectados por Desastres de Origen Natural', available at $<$ https://reliefweb.int/sites/relief web.int/files/resources/CSM_Lineamientos_regionales_personas_desplazadas_por_ desastres.pdf $>$.

A series of decisions were taken relating to specific countries from September 2017 until around January 2018 by the Secretary of State for the Department of Homeland Security. See the timeline at pages 5-7 of US District Court, Ramos et at v Nielsen et al, Order Granting Plaintiffs' Motion for Preliminary Injunction, Case No 18-cv-01554-EMC (3 October 2018).

33 Ibid.

34 See in particular footnote 7 of the Order in Ramos $v$ Nielsen (n. 32).

35 See the update of the case, available at <https://www.uscis.gov/update-ramos-v-nielsen >. 


\subsection{Africa}

At the African Union Summit in January, heads of State and government adopted the African Union Model Law for the Implementation of the African Union Convention for the Protection of and Assistance to Internally Displaced Persons in Africa. ${ }^{36}$ The Convention itself (referred to as the 'Kampala Convention') is recognised as being the first legally-binding treaty addressing internal displacement in the context of disasters and climate change. ${ }^{37}$ Consequently, the entirety of Chapter 3 of the Model Law is devoted to 'Internal Displacement Caused by Disasters', with provisions relating to the prevention of displacement, protecting people during evacuation and throughout displacement, and the facilitation of durable solutions.

At the national level, Mali adopted terms of reference for the elaboration of a national legislative framework on internal displacement during the year, ${ }^{38}$ and Niger was the first country in the region to adopt a binding legal framework for the protection of internally-displaced persons, including those displaced in the context of disasters. ${ }^{39}$ Ethiopia developed a 'Humanitarian and Disaster Resilience Plan' ${ }^{\prime 0}$ focusing extensively on the causes and consequences of climate and disaster-related displacement.

At the sub-regional level, the Tunis Declaration of the Arab African DRR Platform makes extensive reference to displacement as a consequence of disasters as well as a factor engendering differential vulnerability during disasters. ${ }^{41}$ Significantly, with a view to 2019, paragraph 21 of the Declaration urges

36 National Legislative Bodies, 'African Union Model Law for the Implementation of the African Union Convention for the Protection of and Assistance to Internally Displaced Persons in Africa' (12 April 2018), available at <https://www.refworld.org/docid/5afc3a494. html >.

37 See for example Allehone Abebe, The Emerging Law of Forced Displacement in Africa: Development and Implementation of the Kampala Convention on Internal Displacement (Routledge 2017).

38 See Tamara Wood, 'Can Free-Movement Agreements Help People Displaced by Climate Change and Disaster?' (6 February 2018), available at <https://www.kaldorcentre.unsw. edu.au/news/can-free-movement-agreements-help-people-displaced-climatechange-and-disaster>.

39 See UnhCr, 'Niger Becomes the First Country in Africa to Adopt a National Law for the Protection and Assistance of Internally Displaced Persons' (5 December 2018), available at <http://www.globalprotectioncluster.org/wp-content/uploads/Press-Release-IDPLaw-Niger-ENG-PDF.pdf>; Government of Niger, Projet de loi relative a la protection et a l'assistance aux personnes deplacees internes au Niger (2 December 2018).

40 OCHA, 'Ethiopia: Humanitarian and Disaster Resilience Plan' (9 March 2018), available at <https://www.refworld.org/docid/5b34d4244.html>.

41 Declaration of the Sixth High Level Meeting on Disaster Risk Reduction 'Tunis Declaration' (13 October 2018), available at <https://www.preventionweb.net/files/57759_ finaladopteddrafttunisdeclarationı3.pdf $>$. 
African States and the African Union 'to fully integrate and mainstream disaster risk reduction, climate change and Sustainable Development Goals in the roadmap for durable solutions for refugees, returnees and internally displaced persons as a part of the African Union Theme of the Year 2019'.

\subsection{Europe}

The European Union Parliament has taken an active interest in the issue of cross-border displacement in the context of disasters and climate change specifically, as well as in the issue of humanitarian visas more generally. On 16 January 2018, it adopted by 485 votes to 117 with 20 abstentions, resolution number 2017/2086(INI) on women, gender equality and climate justice which focuses heavily on the gender dimensions of displacement and, emphasises that 'responding to climate-induced displacement will be a challenge of paramount importance requiring a complex and comprehensive global strategy grounded in respect for human rights. ${ }^{42}$

The European Commission also recognised the potential relationship between climate change and 'climate-induced migration' in its 'Evaluation of the EU Strategy on adaptation to climate change', issued on 12 November 2018, affirming that 'climate change impacts in third countries can also have spillover effects on Europe, for example by affecting trade routes and patterns and triggering climate-induced migration:43 ${ }^{\prime 3}$ The Evaluation reiterates the policy position adopted in the Commission's earlier Staff Working Document of $2013^{44}$ that climate change adaptation measures, including measures promoting migration as adaptation, can be effective in addressing the risk of displacement. 45

Neither the Parliament nor the Commission call upon the European Union or its Member States to take specific steps to address the incidence of climateand disaster related human mobility to the extent the phenomenon manifests in the (attempted) arrival of non-citizens into European territory.

\subsection{The Pacific}

Although the Pacific Community (SPC) did not adopt any legal or policy provisions relating to human mobility in the context of disasters and climate change in 2018, two national level developments in this region are noteworthy.

\footnotetext{
42 Para. Y.

43 Commission (EU), 'Commission Staff Working Document: Evaluation of the EU Strategy on adaptation to climate change' SWD (2018) 461 final, 12 November 2018, 6.

44 See Commission (EU), 'Commission Staff Working Document: Climate Change, Environmental Degradation, and Migration' swD (2013) 138 final, 16 April 2013.

45 Ibid., 10.
} 
First, in Vanuatu, the National Policy on Climate Change and Disaster-Induced Displacement 'aims to help guide emergency and development planners to work together with the Government of Vanuatu to address the needs of all communities affected by displacement, including people at-risk of displacement, displaced people, internal migrants, people living in informal settlements, and host communities'. After addressing key principles, the Policy first describes four 'system-level interventions' and then eight 'sectoral-level interventions' that are intended to contribute towards enhanced protection from and during displacement and towards the achievement of durable solutions. A human rights-based approach is expressly adopted, and guidance is drawn from key international standards, including for example the IASC Framework on Durable Solutions. ${ }^{46}$

Second, Fiji's brief Planned Relocation Guidelines: A Framework to Undertake Climate Change Related Relocation set out key principles regarding planned relocation, including that this is a measure of last resort after all adaptation measures have been exhausted. ${ }^{47}$ An expressly human rights-based approach is adopted here too, with an emphasis on transparency, participation and consultation. The Guidelines are divided into pre-relocation, during relocation and post-relocation phases, with brief bullet points highlighting key considerations. Standard Operating Procedures remained in process of development at the time the Guidelines were published, but are to be read expressly in conjunction with the Guidelines and represent the 'modus operandi' of the Guidelines.

$46 \quad$ IASC, Framework on Durable Solutions (2010), available at $<$ https://interagencystandingt committee.org/other/documents-public/iasc-framework-durable-solutionsinternally-displaced-persons $>$.

47 National Legislative Bodies, 'Fiji: Planned Relocation Guidelines - A framework to undertake climate change related relocation (2018)' (December 2018), available at $<\mathrm{https://}$ www.refworld.org/docid/5c3c92204.html>. 